\title{
Influence of Spent Bleaching Earth and Misspend Cement on Shear Strength Behaviour of Unsaturated Clays
}

\author{
Kamadi Subhadra ${ }^{1} \mid$ Dr. Ch Bhavannarayana ${ }^{2}$
}

${ }^{1}$ PG Student, Kakinada Institute of Engineering \&Technology- II, Korangi, A.P, India.

${ }_{2}^{2}$ Professor, Kakinada Institute of Engineering \&Technology- II, Korangi, A.P, India.

\section{To Cite this Article}

Kamadi Subhadra and Dr. Ch Bhavannarayana, "Influence of Spent Bleaching Earth and Misspend Cement on Shear Strength Behaviour of Unsaturated Clays", International Journal for Modern Trends in Science and Technology, 6(8): 129-134, 2020.

Article Info

Received on 28-June-2020, Revised on 21-July-2020, Accepted on 02-August-2020, Published on 09-August-2020.

\section{ABSTRACT}

Expansive clay is a major source of undulations induced in any type of structures. Swelling of expansive soils causes serious problems and produces harm to many structures. Many research organizations are doing extensive work on waste materials concerning the viability and environmental suitability. Spent bleaching earth and misspend cement are waste derivatives from oil industry and cement warehouse. To avoid dumping problem and storage problems, it is the best method technique applied in expansive soils. Attempts are made to investigate the stabilization process identified in unconfined compressive strength and tri-axial compressive strength. Stability of any structure depends on strength properties of underground soil on which it is constructed. Structures basically transfer all the loads come on itself directly to the ground. If the underlying soil is not stable enough to support transferred loads then various types of failure occur such as settlement of the structure, cracks and so on. To solve this issue, soil improvement is necessary because it not only lowers the construction cost but also cuts the risk of any damage of structure later on. Numerous improvement methods can be adopted to make ordinary soil stable enough to support the structural loads. In this research work a number of tests may conduct using both ordinary soil and stabilised soil. This thesis explains the strength behavior of SBE treated black cotton soil reinforced with MC. The various percentage of SBE as 5\%,10\%,15\%,20\% and 25\% was used to find out the optimum value of RBI Grade. MC has been randomly included into the SBE treated soil at four different percentages of MC content, i.e. $2 \%, 4 \%, 6 \%$, $8 \%$ and $10 \%$.

KEYWORDS: Expansive soil, UCS, Tri-Axial, SBE and MC

\section{INTRODUCTION}

1.Expansive soils:Expansive soil is one among the problematic soils that has a high potential for shrinking or swelling due to change of moisture content. Expansive soils can be found on almost all the continents on the Earth. Destructive results caused by this type of soils have been reported in many countries. In India, large tracts are covered by expansive soils known as black cotton soils. The major area of their occurrence is the south Vindhyachal range covering almost the entire Deccan Plateau. These soils cover an area of about 200,000 square miles and thus form about $20 \%$ of the total area of India. The primary problem that 
arises with regard to expansive soils is that deformations are significantly greater than the elastic deformations and they cannot be predicted by the classical elastic or plastic theory. Movement is usually in an uneven pattern and of such a magnitude to cause extensive damage to the structures resting on them.

\section{MATERIALS USED AND THEIR PROPERTIES}

The details of the various materials used in the laboratory experimentation are reported in the following sections.

2.1. Expansive Soil: The soil used was a typical black cotton soil collected frommuramallaEast Godavari District, Andhra Pradesh State, India. The properties of soil are presented in the Table 3.1. All the tests carried on the soil are as per IS specifications. Table 3.1 shows the Properties of Expansive Soil.

Table 1: Properties of Expansive Soil

\begin{tabular}{|c|c|c|c|c|}
\hline $\begin{array}{l}\text { S } \\
\text { no }\end{array}$ & Properties & & Value & \\
\hline 1 & $\begin{array}{l}\text { Grain Size } \\
\text { Distribution }\end{array}$ & $\begin{array}{c}\text { Sand Size } \\
\text { Particles } \\
9 \%\end{array}$ & $\begin{array}{c}\text { Silt } \\
\text { Particles } \\
13 \%\end{array}$ & $\begin{array}{c}\text { Clay } \\
\text { particles } \\
78 \%\end{array}$ \\
\hline 2 & Specific gravity & & 2.68 & \\
\hline 3 & $\begin{array}{l}\text { Differential free } \\
\text { swell }\end{array}$ & +2 & 148 & \\
\hline 4 & $\begin{array}{l}\text { Atterberg's } \\
\text { Limits }\end{array}$ & $\begin{array}{c}\text { Liquid } \\
\text { Limit } \\
81.35 \%\end{array}$ & $\begin{array}{c}\text { Plastic } \\
\text { Limit } \\
31.35 \%\end{array}$ & $\begin{array}{c}\text { Plasticity } \\
\text { Index } \\
50.00 \%\end{array}$ \\
\hline 5 & $\begin{array}{l}\text { IS soil } \\
\text { classification }\end{array}$ & & $\mathrm{CH}$ & \\
\hline 6 & $\begin{array}{l}\text { Compaction } \\
\text { Properties }\end{array}$ & $\begin{array}{r}\text { Optimun } \\
\text { Cor } \\
20\end{array}$ & $\begin{array}{l}\text { Moisture } \\
\text { ent } \\
\%\end{array}$ & $\begin{array}{c}\text { Max. Dry } \\
\text { Density } \\
15.22 / \mathrm{m} 3\end{array}$ \\
\hline 7 & $\begin{array}{l}\text { California } \\
\text { Bearing } \\
\text { Ratio(CBR) }\end{array}$ & $\begin{array}{c}\text { Un soal } \\
2 .\end{array}$ & $\begin{array}{l}\text { C.B.R } \\
\%\end{array}$ & $\begin{array}{c}\text { Soaked } \\
\text { C.B.R } \\
1.88 \%\end{array}$ \\
\hline 8 & $\begin{array}{l}\text { Shear Strength } \\
\text { Parameters }\end{array}$ & $\begin{array}{l}\text { Coh } \\
0.5\end{array}$ & $\begin{array}{l}\text { ion } \\
\mathrm{Pa}\end{array}$ & $\begin{array}{c}\text { Angle of } \\
\text { Internal } \\
\text { Friction } \\
0.2 \mathrm{Deg}\end{array}$ \\
\hline
\end{tabular}

2.2 Spent bleaching earth (SBE) is a solid waste generated from the bleaching process in palm oil industry. This solid waste is currently disposed directly in landfills without treatment, causing severe water and air pollution. Which is collected from the oil industry near samalkota.

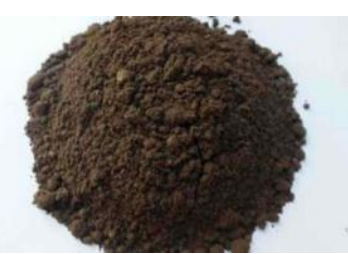

2.3 Waste cement: There are two kinds of waste: industrial waste and domestic waste. We focus on processing industrial waste at cement plants. We process domestic waste as well at some plants. ... After analysing the components of waste, waste can be effectively used as a substitute for cement feedstock or a substitute for thermal energy. Waste collected at jangareddygudem.

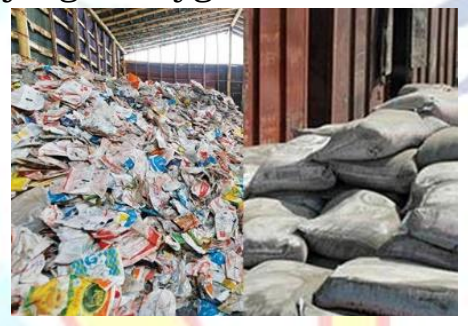

Fig: waste cement

2.4 Soil SBE Mixture with MC: The SBE treated Expansive soil is mixed with various percentage of $\mathrm{MC}$ as $2 \%$ to $10 \%$ with an increment of $2 \%$ to perform modified compaction test.

Table: 2 Expansive soil treated with SBE and MC and Obtained OMC \& MDD Values

\begin{tabular}{|c|l|c|c|}
\hline S.No. & \multicolumn{1}{|c|}{ Sample } & OMC (\%) & MDD (KN/ $\left.\mathbf{m}^{\mathbf{3}}\right)$ \\
\hline 1 & $100 \% \mathrm{ES}$ & 20.55 & 15.22 \\
\hline 2 & $\begin{array}{l}100 \% \mathrm{ES}+20 \% \\
\text { SBE+2\%MC }\end{array}$ & 31 & 14.01 \\
\hline 3 & $\begin{array}{l}100 \% \mathrm{ES}+20 \% \\
\text { SBE+4\%MC }\end{array}$ & 33 & 13.68 \\
\hline 4 & $\begin{array}{l}100 \% \mathrm{ES}+20 \% \\
\text { SBE+6\%MC }\end{array}$ & 35.12 & 13.21 \\
\hline $\mathbf{5}$ & $\begin{array}{l}\mathbf{1 0 0} \% \mathbf{E S ~ + ~ 2 0} \% \\
\text { SBE+8\%MC }\end{array}$ & $\mathbf{3 6 . 2 3}$ & $\mathbf{1 3 . 0 1}$ \\
\hline 6 & $\begin{array}{l}100 \% \mathrm{ES}+20 \% \\
\mathrm{SBE}+10 \% \mathrm{MC}\end{array}$ & 37.3 & 12.89 \\
\hline
\end{tabular}




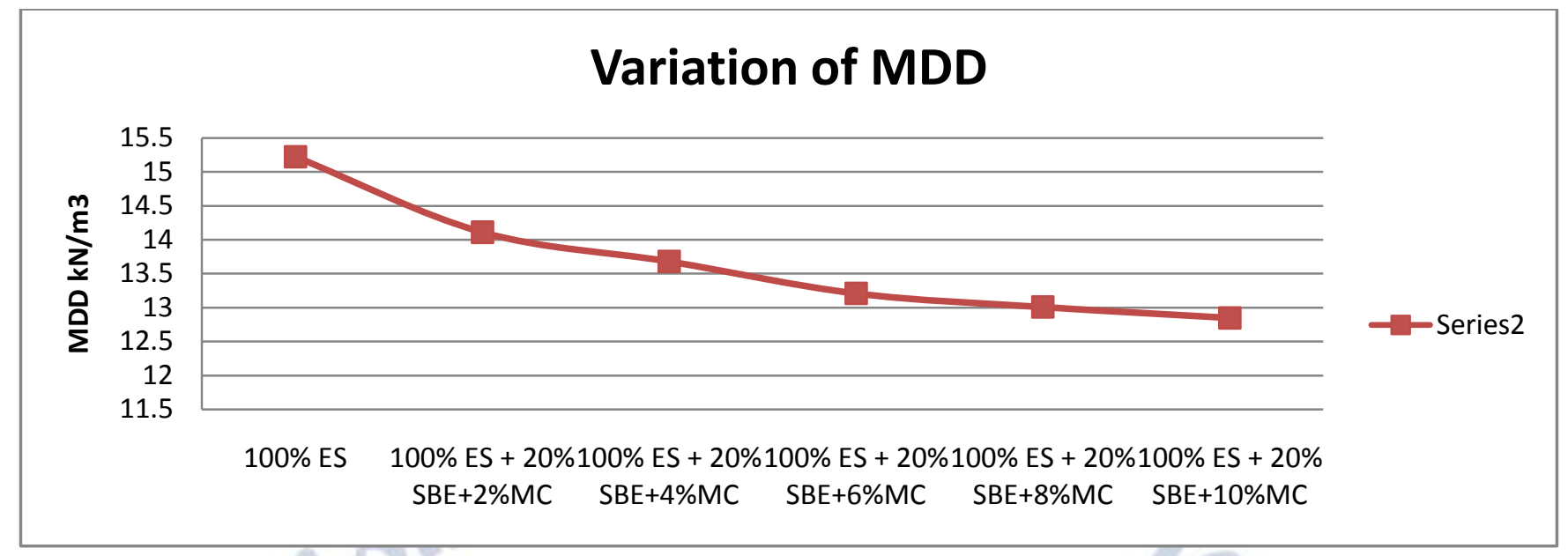

Fig: 1Shows the OMC for treated with 20\% SBE and different percentages of MC to the Expansive soil.

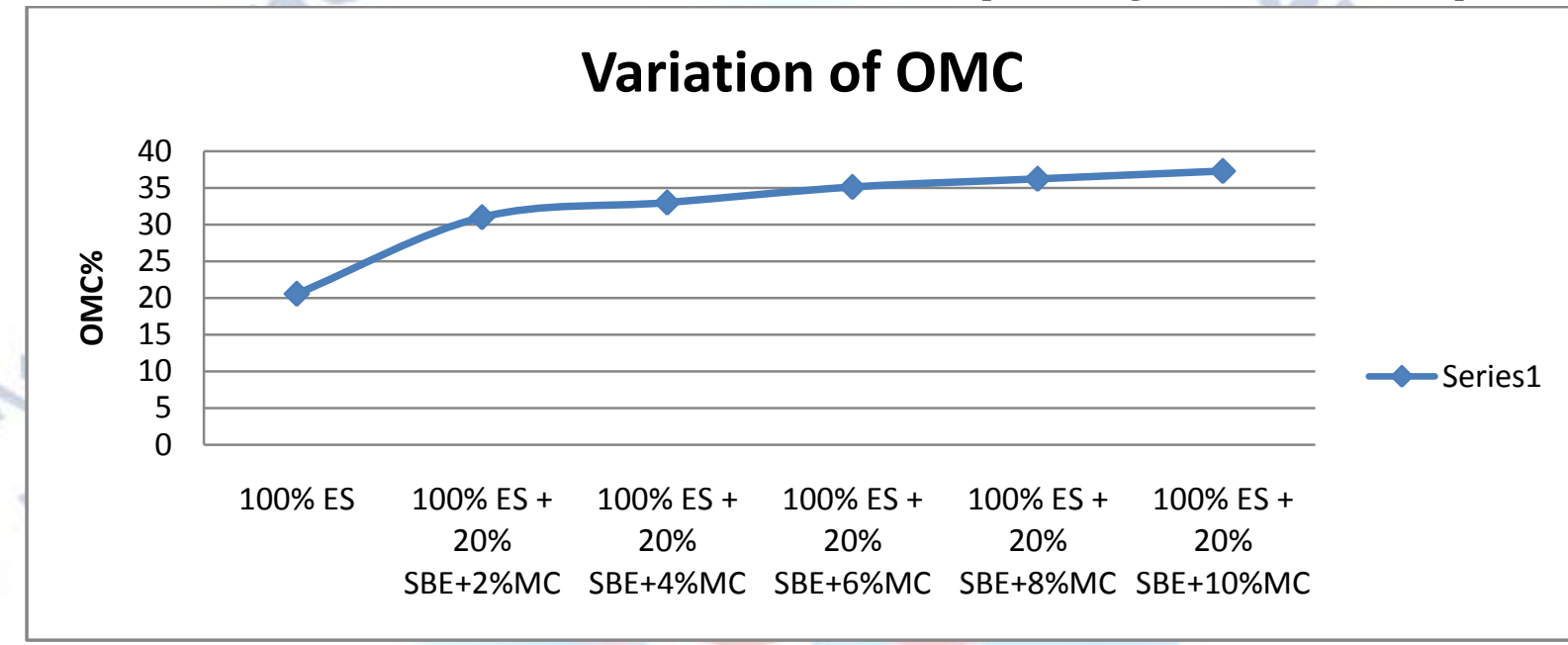

Fig:2 Shows the MDD for treated with 20\% SBE and different percentages of MC to the Expansive soil.

Table 3 Expansive soil treated with SBE and MC and Obtained DFS Values

\begin{tabular}{|l|l|c|}
\hline S.No. & Particulars & DFS \% \\
\hline 1 & $100 \% \mathrm{ES}$ & 148 \\
\hline 2 & $100 \% \mathrm{ES}+20 \% \mathrm{SBE}$ & 89 \\
\hline 3 & $100 \% \mathrm{ES}+20 \% \mathrm{SBE}+5 \% \mathrm{MC}$ & 76 \\
\hline 4 & $100 \% \mathrm{ES}+20 \% \mathrm{SBE}+10 \% \mathrm{MC}$ & 71 \\
\hline 5 & $100 \% \mathrm{ES}+20 \% \mathrm{SBE}+15 \% \mathrm{MC}$ & 65 \\
\hline 6 & $100 \% \mathrm{ES}+20 \% \mathrm{SBE}+20 \% \mathrm{MC}$ & 61 \\
\hline 7 & $100 \% \mathrm{ES}+20 \% \mathrm{SBE}+25 \% \mathrm{MC}$ & \multicolumn{2}{|l}{} \\
\hline
\end{tabular}

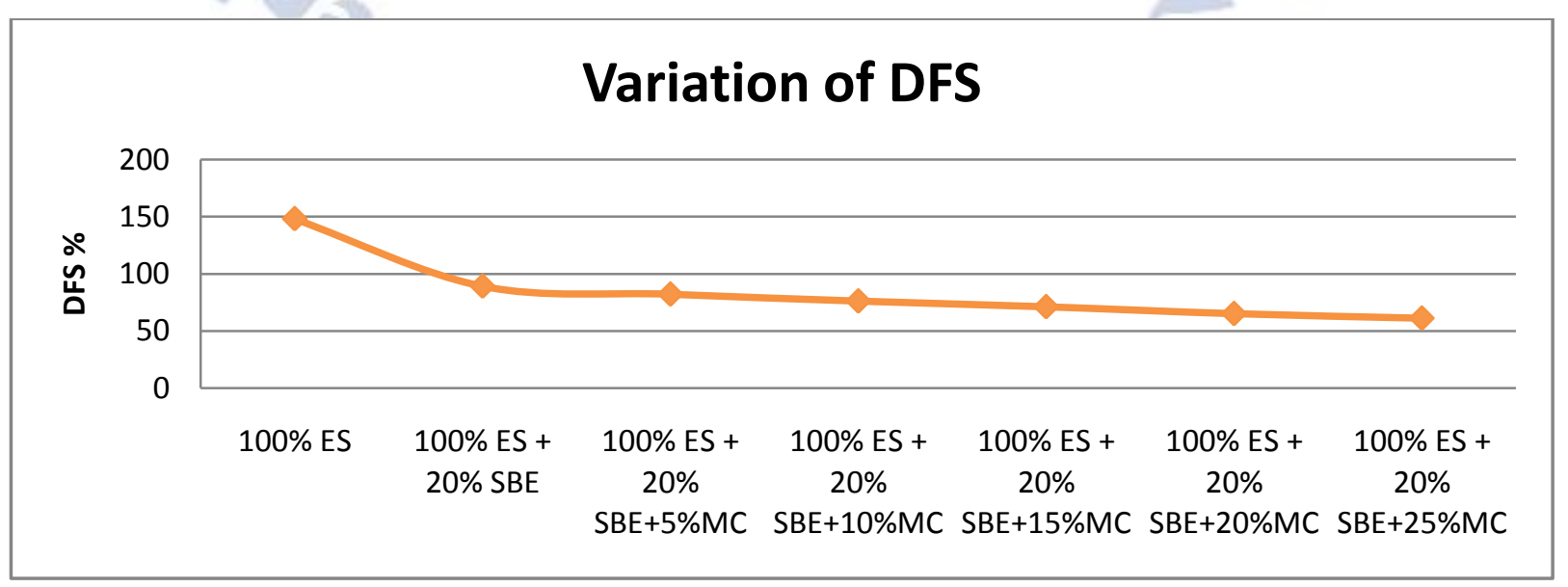


Fig: 3 Shows the DFS for treated with 20\% SBE and different percentages of MC to the Expansive soil Table 4 Expansive soil treated with SBE and MC and Obtained Soaked \& Un-soaked CBR values

\begin{tabular}{|c|c|c|c|}
\hline S.No. & Particulars & CBR \% (Un-Soaked) & CBR \% (Soaked) \\
\hline 1 & $100 \% \mathrm{ES}$ & 2.58 & 1.88 \\
\hline 2 & $100 \% \mathrm{ES}+25 \% \mathrm{SBE}$ & 5 & 4 \\
\hline 3 & $100 \% \mathrm{ES}+20 \% \mathrm{SBE}+2 \% \mathrm{MC}$ & 5.5 & 4.38 \\
\hline 4 & $100 \% \mathrm{ES}+20 \% \mathrm{SBE}+4 \% \mathrm{MC}$ & 6.2 & 4.98 \\
\hline 5 & $100 \% \mathrm{ES}+20 \% \mathrm{SBE}+6 \% \mathrm{MC}$ & 7 & 5.8 \\
\hline 6 & $100 \% \mathrm{ES}+20 \% \mathrm{SBE}+8 \% \mathrm{MC}$ & 8.5 & 6.6 \\
\hline 7 & $100 \% \mathrm{ES}+20 \% \mathrm{SBE}+10 \% \mathrm{MC}$ & 8.4 & 6.4 \\
\hline
\end{tabular}

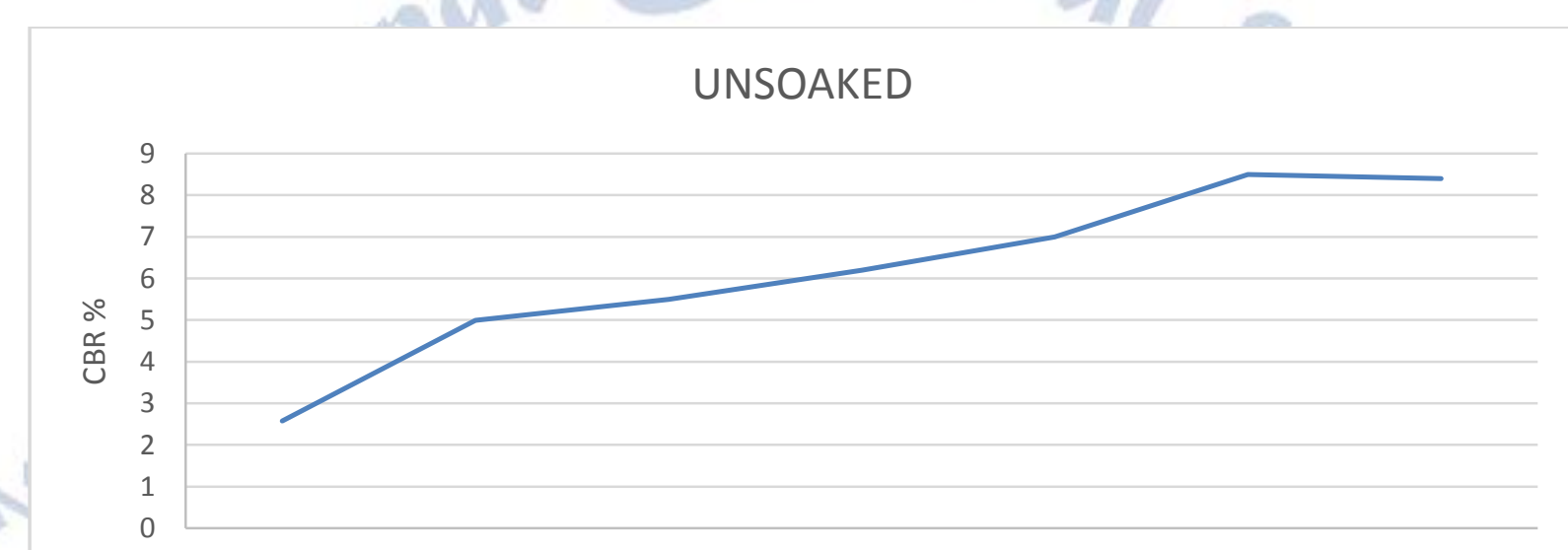

$100 \% \mathrm{ES} \quad 100 \% \mathrm{ES}+25 \% 100 \% \mathrm{ES}+20 \% 100 \% \mathrm{ES}+20 \% 100 \% \mathrm{ES}+20 \% 100 \% \mathrm{ES}+20 \% 100 \% \mathrm{ES}+20 \%$

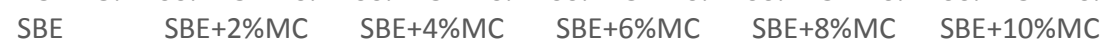

Fig: 4 Shows the Variation of Un-soaked CBR values with $20 \%$ of SBE and different percentages of MC

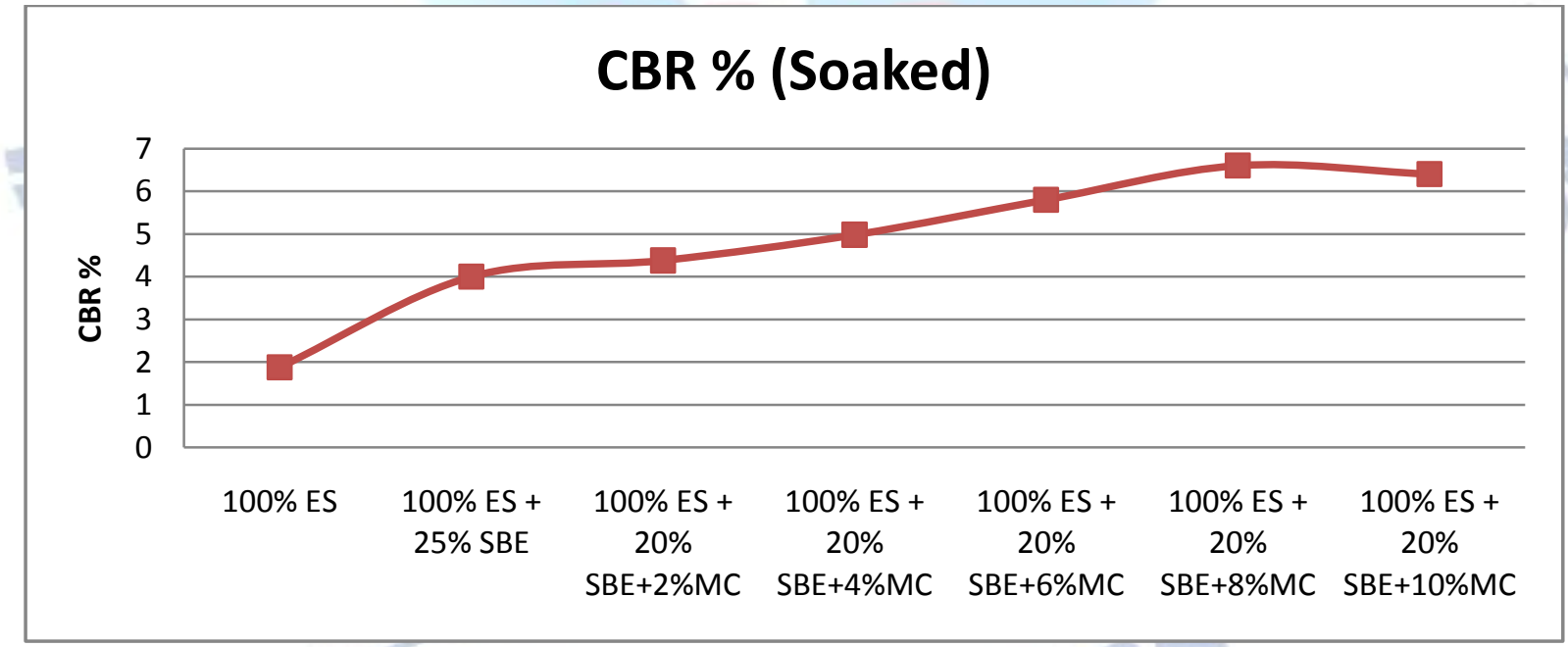

Fig: 5 Shows the Variation of Soaked CBR values with 20\% of SBE and different percentages of MC Table 5 Expansive soil treated with SBE and MC and Obtained UCS Values

\begin{tabular}{|c|c|c|c|c|c|}
\hline $\mathbf{S}$ & \multirow{2}{*}{ Particulars } & \multicolumn{4}{|c|}{ Days UCS(kN/m2) } \\
\cline { 3 - 6 } No & & $\mathbf{0}$ & $\mathbf{7}$ & $\mathbf{1 4}$ & $\mathbf{2 8}$ \\
\hline 1 & $100 \% \mathrm{ES}$ & 350 & 350 & 350 & 350 \\
\hline 2 & $100 \% \mathrm{ES}+20 \% \mathrm{SBE}$ & 571 & 680 & 1001 & 1050 \\
\hline 3 & $100 \% \mathrm{ES}+20 \% \mathrm{SBE}+2 \% \mathrm{MC}$ & 740 & 880 & 970 & 1100 \\
\hline 4 & $100 \% \mathrm{ES}+20 \% \mathrm{SBE}+4 \% \mathrm{MC}$ & 950 & 1025 & 1200 & 1340 \\
\hline 5 & $100 \% \mathrm{ES}+20 \% \mathrm{SBE}+6 \% \mathrm{MC}$ & 1229 & 1350 & 1430 & 1570 \\
\hline
\end{tabular}




\begin{tabular}{|c|c|c|c|c|c|}
6 & $100 \% \mathrm{ES}+20 \% \mathrm{SBE}+8 \% \mathrm{MC}$ & 1340 & 1510 & 1740 & 1740 \\
\hline 7 & $100 \% \mathrm{ES}+20 \% \mathrm{SBE}+10 \% \mathrm{MC}$ & 1295 & 1440 & 1700 & 1720 \\
\hline
\end{tabular}

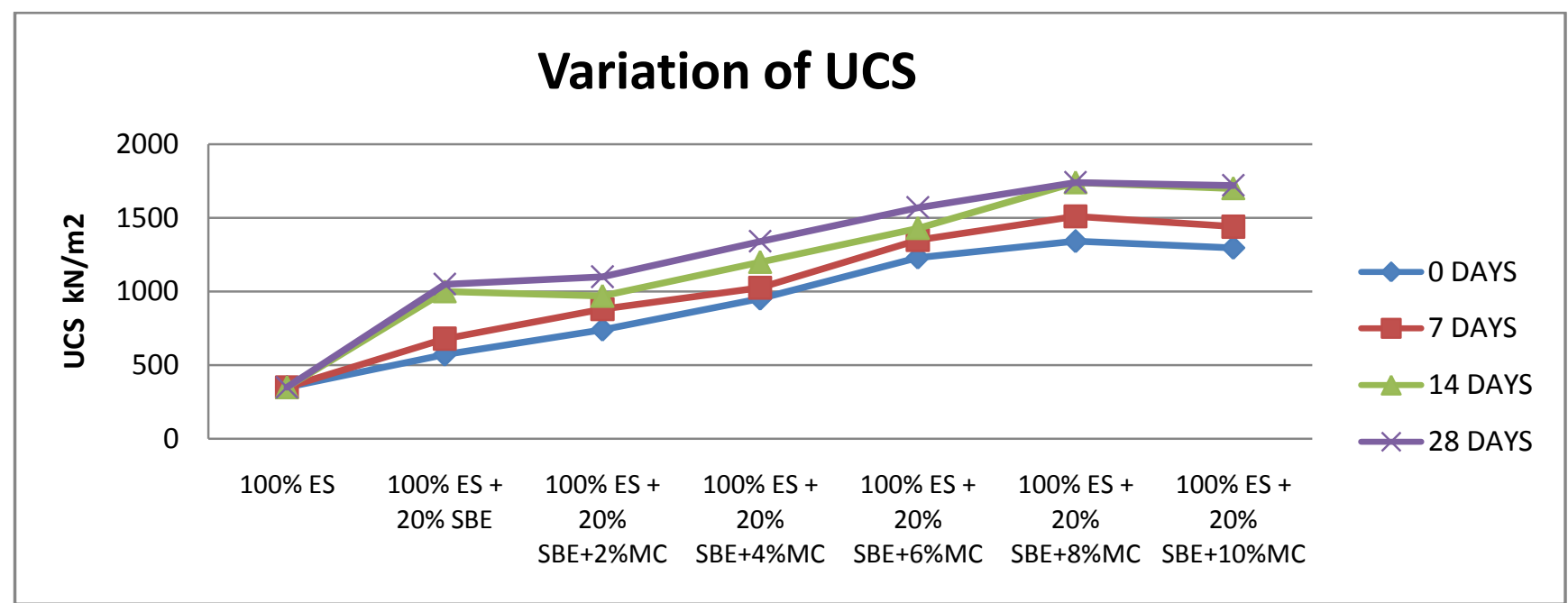

Fig: 6 Shows the UCS for treated with 20\% SBE and different percentages of MC to the Expansive soil Table 6: Table showing shear strength parameters:

\begin{tabular}{|c|c|c|c|c|c|c|c|}
\hline \multirow{3}{*}{$\begin{array}{c}\text { Materials } \\
\text { added to the } \\
\text { soil }\end{array}$} & \multirow{3}{*}{$\begin{array}{l}\text { Percenta } \\
\text { ge of } \\
\text { materials } \\
\text { added to } \\
\text { the soil }\end{array}$} & \multicolumn{6}{|c|}{ Shear strength properties (KPa) } \\
\hline & & \multicolumn{2}{|c|}{1 day } & \multicolumn{2}{|c|}{7 days } & \multicolumn{2}{|c|}{ 14days } \\
\hline & & $\begin{array}{c}\text { Cohesio } \\
\mathrm{n}, \mathrm{C}_{\mathrm{u}} \\
\left(\mathrm{kg} / \mathrm{cm}^{2}\right)\end{array}$ & $\begin{array}{c}\text { Angle } \\
\text { of } \\
\text { intern } \\
\text { al } \\
\text { frictio } \\
\mathrm{n}, \phi, \\
\text { (Deg.) }\end{array}$ & $\begin{array}{c}\text { Cohesio } \\
\mathrm{n}, \mathrm{C}_{\mathrm{u}} \\
\left(\mathrm{kg} / \mathrm{cm}^{2}\right)\end{array}$ & $\begin{array}{c}\text { Angle } \\
\text { of } \\
\text { intern } \\
\text { al } \\
\text { frictio } \\
\text { n, } \phi, \\
\text { (Deg.) }\end{array}$ & $\begin{array}{c}\text { Cohesio } \\
\mathrm{n}, \mathrm{C}_{\mathrm{u}} \\
\left(\mathrm{kg} / \mathrm{cm}^{2}\right)\end{array}$ & $\begin{array}{l}\text { Angle of } \\
\text { internal } \\
\text { friction, } \\
\phi \text {, (Deg.) }\end{array}$ \\
\hline $\begin{array}{l}\text { Without } \\
\text { material }\end{array}$ & 0 & 0.56 & $2^{0}$ & 0.56 & -- & 0.56 & -- \\
\hline \multirow{4}{*}{$\mathrm{SBE}$} & 2 & 0.61 & $3^{0}$ & 1.11 & $5^{0}$ & 1.28 & $6^{0}$ \\
\hline & 4 & 0.72 & $5^{0}$ & 1.23 & $6^{0}$ & 1.32 & $7^{0}$ \\
\hline & 6 & 0.65 & $6^{0}$ & 1.15 & $8^{0}$ & 1.26 & $7^{0}$ \\
\hline & 8 & 0.63 & 70 & 1.10 & $8^{0}$ & 1.24 & $8^{0}$ \\
\hline \multirow{4}{*}{$\begin{array}{c}100 \% \mathrm{ES}+20 \% \\
\mathrm{SBE}+\% \mathrm{MS}\end{array}$} & 5 & 0.79 & $2^{0}$ & 1.25 & $4^{0}$ & 1.36 & $6^{0}$ \\
\hline & 10 & 0.89 & $3^{0}$ & 1.28 & $5^{0}$ & 1.39 & $7^{0}$ \\
\hline & 15 & 0.86 & 40 & 1.25 & $5^{0}$ & 1.33 & $6^{0}$ \\
\hline & 20 & 0.83 & 40 & 1.34 & $6^{0}$ & 1.32 & 60 \\
\hline
\end{tabular}

\section{CONCLUSIONS}

- The results of Liquid Limit tests on expansive soil treated with different percentages of SBE can be seen that with increase in percentage of SBE the liquid limit of soil goes on decreasing from $81.35 \%$ to $60.21 \%$ when SBE is increased from 0 to $25 \%$. The results of plastic Limit tests on expansive soil treated with different percentages of SBE can be seen that with increase in percentage of SBE the plastic limit of soil goes on decreasing from $31.55 \%$ to $50.85 \%$ when SBE is increased from 0 to $25 \%$. The results of Plasticity Index of expansive soil treated with different percentages of SBE, it can be seen that with increase in percentage of SBE the plasticity Index of soil goes on decreasing from $50 \%$ to $9.36 \%$ when SBE is increased from Oto $25 \%$.

- The results of Compaction tests on expansive soil treated with different percentages of SBE 
can be seen that with Decrease of MDD with the increasing addition of SBE, while the other side of OMC increasing. The MDD of soil goes on decreasing from $0 \%$ to $8 \%$ when SBE added at $20 \%$. The results of Compaction tests on expansive soil treated with different percentages of SBE can be seen that with Decrease of MDD with the increasing addition of SBE, while the other side of OMC increasing. The OMC of soil goes on increasing from $0 \%$ to $42 \%$ when SBE added at $20 \%$. The results of Compaction tests on expansive soil treated with $20 \%$ SBE and different percentages of MC can be seen that with Decrease of MDD with the increasing addition of MC and 20\% SBE, while the other side of OMC increasing. The MDD of soil goes on decreasing from $0 \%$ to $14.58 \%$ when SBE added at $20 \%$ as shown in fig. 5.6. The results of Compaction tests on expansive soil treated with $20 \%$ SBE and different percentages of $\mathrm{MC}$ can be seen that with Decrease of MDD with the increasing addition of SBE, while the other side of OMC increasing. The OMC of soil goes on increasing from $0 \%$ to $76.30 \%$ when SBE added at $20 \%$ and $8 \%$ MC.

- The results of DFS tests on expansive soil treated with different percentages of SBE can be observed that the Decrease of DFS with the increasing addition of SBE. The DFS of soil goes on decreasing from $0 \%$ to $76.10 \%$ at added $20 \%$ SBE. The results of DFS tests on expansive soil treated with $20 \%$ SBE and different percentages of MC can be seen that the Decrease of DFS with the increasing addition of MC and 20\% SBE. The DFS of soil goes on decreasing from $0 \%$ to $142 \%$ when SBE added at $10 \%$.

- The results of CBR tests on expansive soil treated with different percentages of SBE can be seen that with increase of un-Soaked CBR with the increasing addition of SBE. The Un-Soaked CBR of soil goes on increasing from $0 \%$ to $93.70 \%$ by adding $20 \%$ SBE. The results of CBR tests on expansive soil treated with different percentages of SBE can be seen that with increase of Soaked CBR with the increasing addition of SBE. The Soaked CBR of soil goes on increasing from $0 \%$ to $91 \%$ when SBE. The results of CBR tests on expansive soil treated with $20 \%$ SBE and different percentages of $\mathrm{MC}$ can be seen that the increase of Un-Soaked CBR with the increasing addition of MC and 20\% SBE. The Un-Soaked
CBR of soil goes on increasing from $0 \%$ to $229 \%$ when SBE added at $20 \%$ and different percentages of MC. The results of CBR tests on expansive soil treated with $20 \% \mathrm{SBE}$ and different percentages of $\mathrm{MC}$ can be seen that the increase of Soaked CBR with the increasing addition of MC and 8\% SBE. The Soaked CBR of soil goes on increasing from $0 \%$ to $251 \%$ when SBE added at $20 \%$ and different percentages of MC.

- The results of UCS tests on expansive soil treated with different percentages of SBE can be seen that the increase of UCS with the increasing addition of SBE. The UCS of soil goes on increasing from $0 \%$ to 200 for 28days by adding $20 \%$ SBE.The results of UCS tests on expansive soil treated with $20 \% \mathrm{SBE}$ and different percentages of $\mathrm{MC}$ can be seen that the increase of UCS with the increasing addition of MC and 20\% SBE. The UCS of soil goes on increasing from $0 \%$ to $397 \%$ for 28 days when SBE added at $8 \%$ and different percentages of MC.

\section{REFERENCES}

[1] Ramesh, H.N., K.V. Manoj Krishna and H.V. Mamatha (2010) "Compaction and strength behaviour of RBI-coir fiber treated black cotton soil", geomechanics and Engineering, Vol. 2., No. 1 19-28.

[2] Kaniraj, S.R. and Vasant, G.H. (2001), "Behavior of cement-stabilized fiber reinforced fly ash soil mixture", Geotech. Geoenviron. Eng. J, 574-584.

[3] Kaniraj, S.R. and Gayathri, V. (2003), "Geotechnical Behavior of fly ash mixed with randomly oriented fiber inclusions", Geotext. Geomembranes, 21, 123-149.

[4] Nagu, P.S., Chandrakaran, S. and Sankar, N. (2008), "Behaviour of RBI stabilized clayey soil reinforced with Nylon fibers", Proceedings of '08 International Conference on Geotechnical and Highway Engineering, Geotropika, Kuala Lumpar, Malaysia, May.

[5] Kavitha. S and Dr. T. Felix Kala, "Bamboo Fibre Analysis by Scanning Electron Microscope Study". International Journal of Civil Engineering and Technology (IJCIET), 7(4), 2016, pp.234-24.

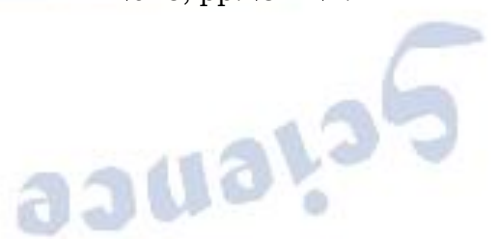

